\title{
Isolation, Characterization and Identification of Bacteria Live in Extreme Conditions: Example of Gilindire Cave
}

\section{Yağmur Atakav and Rozelin Aydın*}

Adana Science and Technology University, Faculty of Engineering, Bioengineering Department; Adana, Turkey

*Corresponding Author: Rozelin Aydın, Adana Science and Technology University, Faculty of Engineering, Bioengineering Department; Adana, Turkey.

DOI: 10.31080/ASMI.2020.03.0507
Received: January 24, 2020

Published: February 08, 2020

(C) All rights are reserved by Yağmur Atakav and Rozelin Aydın.

\begin{abstract}
Caves are extreme ecosystems that are too limited in nutrient with stable temperature, high humidity. Gilindire Cave, located in Mersin; Turkey, contains samples from Ice Age and is the only place known to represent evidence of the last climate changes in in the Eastern Mediterranean. Therefore, Gilindire Cave distinguishes itself from other caves in Turkey with its "representative" and "individual" features. In this study bacterial load of Gilindire Cave was investigated by using culture dependent and culture independent methods. Samples were cultured on R2A petri plates and distinct looking colonies were isolated. After isolation, $16 \mathrm{~S}$ rRNA PCR analysis was performed. 58 isolates were obtained after cultivation experiments. However, further investigation was completed on 30 individual isolate due to elimination of isolates. Crystal formation was investigated with B-4 media and it was seen that 3 of the isolates was unable grow on this media while the rest 27 were able to grow successfully. Twenty of the isolates were chosen and send to analysis. Most abundant phyla included Actinobacteria (39\%) followed by Proteobacteria (\%33), Firmicutes $(17 \%)$ and Bacteriodetes (5,5\%) as well as uncultured organism (5,5\%) was found, usable results could not be obtained from two of the isolates.

Keywords: Bacteria; Gilindire Cave; Isolation; Characterization; Identification
\end{abstract}

\section{Introduction}

Caves are defined as a type of natural, rocky cavity under the ground that receives too little to no light and also accessible to humans. They are formed by rocks such as gypsum, granite, quartzite, and talus but most commonly by calcareous rocks such as, limestone [1]. Caves are extreme ecosystems that are limited in nutrient with stable temperature, high humidity and the only photosynthetic activity relies on light beam comes from the Entrance Zone. Caves are generally isolated places which are not only limit but also protect the microflora that able to live in that environment $[2,3]$. Caves are under the spotlight due to several reasons. Extreme and dark conditions of caves represent ideal ecosystems to study for many different branches such as biological, geological, environmental and chemical studies. Also, the unique and not fully explored cave ecosystem provides an excellent opportunity for the discovery of novel microorganisms and biological byproducts such as ethanol production, biotechnologically important and new enzymes, antibiotics and even cancer treatments [4,5]. Furthermore, cave research helps finding answers to unanswered questions about the role of microorganisms in cave formation as well as the relation between mineral surfaces and microbial mats, and the effect of human activities, such as tourism, on microbial cave ecology. Microorganisms play a key role in many different aspects in caves, it also influence on mineralogy such as mineral precipi- tation [6-8]. Even though it is not proven yet, many cave deposits are considered to have microbiological origins. For the last twenty years, the progression of the cultivation independent approaches has provided a myriad of information about bacterial community composition, the abundance of different taxa and their possible function in different habitats. However, there are still so little known regarding the process leading to the observed diversity in different ecosystems and how environmental factors contribute to shaping microbial communities $[9,10]$.

Compared with other countries in the world, Turkey is a cave paradise and there are about 40.000 caves in the country. Karstification, which is an important geological-geomorphological characteristic in terms of cave formations, is located in the Western and Central Taurus Mountains in Turkey (http://yigm.kulturturizm. gov.tr/TR,10335/magara-turizmi.html). Despite the huge numbers of cave in Turkey, too limited studies have been carried out on microbiological studies in these caves.

Present study aimed to isolate, characterize and identify the bacterial load by using both culture dependent and culture independent molecular techniques at Gilindire Cave. At the same time, the antimicrobial properties of the cave samples were determined. Spectacularly, Gilindire Cave is unique as being one and only representative cave of the transition phase after the last glacial climate 
change of the Quaternary Period, in the East Mediterranean Region [11]. Even though there are a few studies conducted about geology, this is the first study where the geomicrobiology of Gilindire Cave is investigated.

\section{Materials and Methods}

Study site and sample collection

Gilindire Cave which is also known as Aynalıg̈l Cave (36 $07^{\circ} 58.08^{\prime \prime} \mathrm{N} 33^{\circ} 24^{\prime} 11.04$ "E) is found by a shepherd in 2000. Gilindire Cave is located 9km east of the district Aydıncık in Mersin, Mediterranean cost of Turkey [11,12]. The cave is $555 \mathrm{~m}$ long and has developed along NE-NW trending faults in limestone and dolomic limestone of Cambrian Age. Gilindire Cave, like a live laboratory, contains samples from Ice Age and is the only place known to represent evidence of the last climate changes.

All required permissions were taken from the related government agencies prior to study in Gilindire Cave. Samples were taken from cave walls and speleothem of cave by using sterile swabs (Figure 1). Swabs were wetted sterile tap water $(\mathrm{pH}=7.2-7.8$ ) and immersed in $3 \mathrm{~mL}$ of sterile tap water in capped test tubes, placed on ice, and transported back to the laboratory for same-day processing.
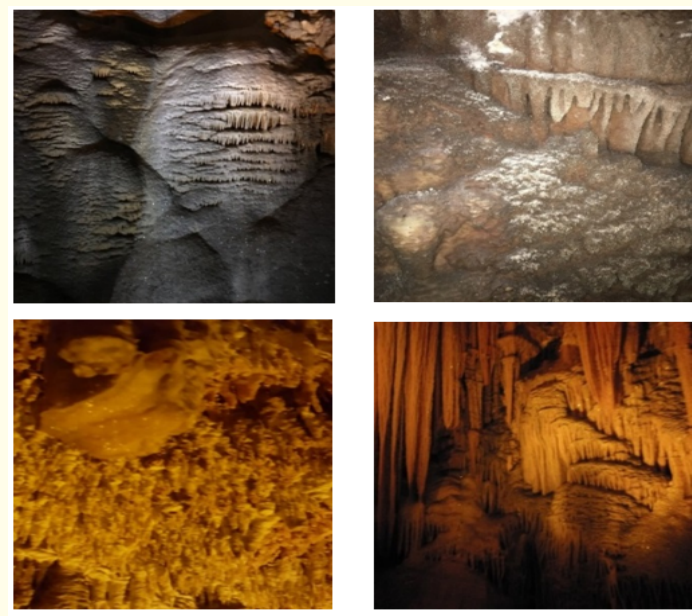

Figure 1: Sampling locations at Gilindire Cave.

\section{Isolation and characterization}

To enumerate heterotrophs and to allow visual assessment of morphological diversity, samples was vortexed for $5 \mathrm{~min}$ and then $0.1 \mathrm{~mL}$ volumes of five serial dilutions was plated on R2A medium in the laboratory. Plates were incubated in $30^{\circ} \mathrm{C}$ for two months. For the selection of unique bacteria for identification, first, during the 2-months period of incubation, morphologically distinct colonies were selected for isolation from each dilution series $\left(10^{-1}\right.$ to $10^{-5}$ ) as they appeared. This was repeated 3 times after which a single colony was transferred to liquid R2A medium until pure colonies were obtained. Cell morphology and purity of the isolates were checked by phase-contrast microscopy. The isolates that have similar bacterial and colony morphology were also eliminated. Gram-staining was carried out according to the standard protocol [13].

Catalase test was used in order to determine the presence of the enzyme cytochrome oxidase in the isolated colonies. For the test, one loop full of 18 to 24 hour colony were taken and placed on a clean glass slide. One drop of $5 \% \mathrm{H}_{2} \mathrm{O}_{2}$ solution was added to the sample. Visible bubble formation was considered as a positive result. Urease test was used to determine the colonies that can able to hydrolyze urea using the enzyme urease. For the test, bacteria were inoculated on to Christensen agar on $33^{\circ} \mathrm{C}$ degrees for 1 to 5 days. Amylase test were performed to show the bacteria that have the ability to hydrolyze starch using amylase enzyme. Isolates were cultured on starch agar and cultured for 3 to 7 days. After incubation iodine was added on to medium and color change was observed. As the indicator of starch, iodine changes its yellow color to black in the presence of starch on the media [14].

\section{Crystal formation}

B-4 media is traditional test medium and being used widely to investigate calcite precipitation and crystal production of the bacteria. Calcite precipitation may indicate that bacteria have a role in the cave formation. In order to see the crystal formation, isolates were cultured on the B- 4 medium and the media was observed under light microscope $[15,16]$.

\section{Molecular analysis of the isolates}

DNA was extracted by using Fast DNA Spin Kit (MP Biomedicals; Solon, OH, USA) according to the manufacturer's instruction for molecular analysis of the isolates. Agarose gel electrophoresis was performed in order to confirm the extraction of DNA. After the conformation of DNA on gel, the amount of DNA extracted from the isolates was measured with Qubit 2.0 (Invitrogen) by using Qubit dsDNA BR Assay Kit (Invitrogen; Waltham, Massachusetts, USA). Universal bacterial primers 27F (forward 5'- AGA GTT TGA TCC TGG CTC AG -3'), and 1492R (reverse 5'- GGT TAC CTT GTT ACG ACT T - $3^{\prime}$ ) [17] were used as primers for the PCR. PCR performed with the reagents from New England Biolabs (NEB; Ipswich, Massachusetts, USA). Extracted genes were amplified using 95으 for 2 min for initial denaturation, then 35 cycles of $95^{\circ} \mathrm{C} 30 \mathrm{sec}, 52^{\circ} \mathrm{C}$ $40 \mathrm{sec}, 72^{\circ} \mathrm{C} 1,30 \mathrm{~min}$, with an extension period of $72^{\circ} \mathrm{C}$ for $5 \mathrm{~min}$. PCR products was examined by gel electrophoresis. PCR products purified and concentrated with the DNA Clean and Concentrator ${ }^{\mathrm{TM}}$ 100 (Zymo; Irvine, California, USA), according to the manufacturer's instructions. Each sample concentration was measured with Qubit dsDNA BR Assay Kit (Invitrogen; Waltham, Massachusetts, USA) and fixed at 50ng DNA per microliter by dilution. Cleaned and 
concentrated products were sent for sequence analysis in order to identify isolates. Sequencing of the almost complete $16 \mathrm{~S}$ rRNA gene was performed by the company (https://www.gatc-biotech. com/). Reverse and forward gene sequences were compiled manually checked for misreading with alignment of Bioedit (www.mbio. nscu.edu/bioedit/bioedit.html). Closely related 16S rRNA gene sequences were identified by using the BLASTN algorithm (http:// ncbi.nlm.nih.gov/blast).

\section{Results}

Bacterial isolation and characterization

58 isolates were obtained after cultivation however further investigation was completed on 30 individual isolate due to elimination of isolates. Some of the isolated colonies showed in the figure 2.
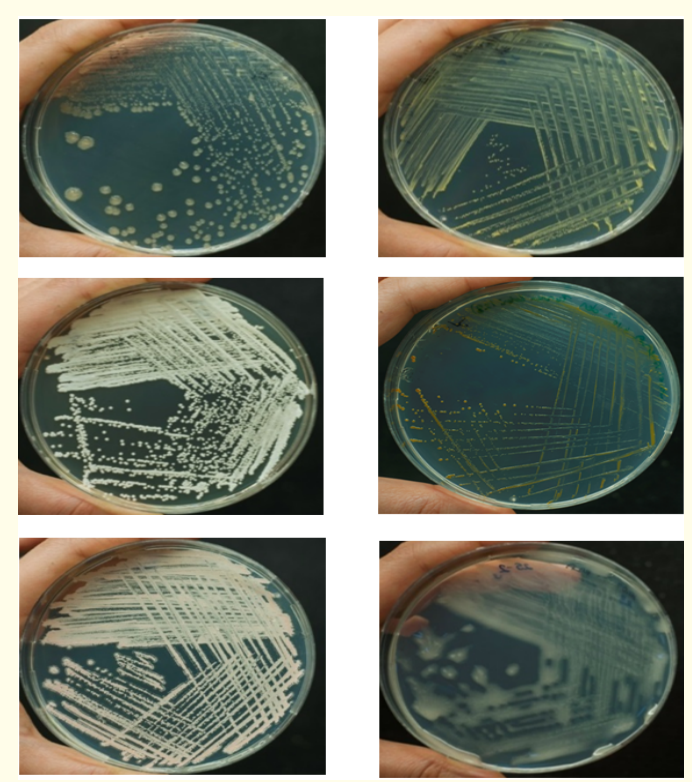

Figure 2: Isolated colonies on R2A media. Left to right sample 4, 2, 11, 27, 19 and 25 respectively.

Phenotypic properties of the isolates were determined by gram staining and observing motility from the samples taken liquid media. Morphologic characteristics of the isolates are shown in the table 1 . According to the gram staining, 15 of the isolates were found to be gram negative while 13 of them were gram positive. 2 of the isolates could not be stained with gram staining. Only 7 isolates showed motility. Catalase, amylase and urease tests were done for each sample. Biochemical tests of isolates indicated that, except for 4 , all of the isolates were catalase positive. Among all of the isolates, 13 of the isolates showed negative results for urease test. Amylase test also gave 17 negative results. All of the results regarding characterization tests were shown in table 1 .

\section{Crystal formation}

Crystal formation was investigated with B-4 [15] media and it was seen that 3 of the isolates were unable grow on this media while the rest 27 were able to grow successfully. Crystal formation observed on 21 isolates while 6 isolates were not capable to produce crystals on the same conditions (Table 1 ).

\section{Sanger sequence analysis}

Amplified DNA extracts were loaded on the gel and it was confirmed all PCR products gave bands on the $1500 \mathrm{bp}$ length since $27 \mathrm{~F}-1492 \mathrm{R}$ primers give products approximately at $1500 \mathrm{bp}$.

Twenty of the isolates were chosen and send to analysis. Each sequence deposited in genbank with accession number MG859501MG859518. Among the isolates; 7 Actinobacteria (39\%), 6 Proteobacteria (\%33), 3 Firmicutes (17\%) and 1 Bacteriotedes $(5,5 \%)$ as well as 1 uncultured organism $(5,5 \%)$ was found, two of the isolates didn't give usable results, for this reason number of the samples are accepted as eighteen. Four isolates of the Proteobacteria were grouped with the $\alpha$-, while the remaining two were grouped with the $\beta$ - and $\gamma$-Proteobacteria (Table 2).

\section{Discussion}

Gilindire Cave is microbiologically unexplored and unique place since its formation shows three different geological period of earth. Cave studies are increasing around the world with the hope to find novel microorganisms that are not discovered yet. These studies aim not only to isolate and characterize the bacteria, which might biotechnologically important, but also to present microbial diversity of the environment $[1,18]$. In order to achieve this aim, isolates were obtained by culture dependent methods and identified with culture independent method. The relatives of the following phyla were represented Actinobacteria (39\%) followed by Proteobacteria (\%33), Firmicutes $(17 \%)$ and Bacteriodetes $(5,5 \%)$ as well as uncultured organism $(5,5 \%)$. Previous studies showed that Proteobacteria, Actinobacteria, Firmicutes and Bacteriodetes are the dominant phyla in cave environments [19-22]. Ikner., et al. [19] found Firmicutes (66\%), Actinobacteria (19\%) and Proteobacteria (15\%) from the rock samples in Kartchner Caves on R2A media. Ortiz., et al. [21] identified Proteobacteria (52\%) and Actinobacteria (13\%) in Kartchner Caves in another site of the cave [22] found Actinobacteria (46 - 50\%), Proteobacteria (22 - 25\%) and Acidobacteria phyla (6 - 7\%) in Oylat Cave. On the contrary, the study conducted by Barton., et al. (2007) showed dominant Actinobacteria phylum with $80 \%$ of the total community of bacteria. Although percentages of the phyla are changing, our results are compatible with the findings of other researchers and also supports Porca., et al. (2012) who suggested there is a core group of microorganisms in caves even though each cave is unique in terms of bacterial diver- 


\begin{tabular}{|c|c|c|c|c|c|c|c|c|}
\hline $\begin{array}{c}\text { Sample } \\
\text { Code }\end{array}$ & Cell Morphology & $\begin{array}{l}\text { Gram } \\
\text { Stain }\end{array}$ & Motility & Catalase & Amylase & Urease & B-4 Cultivability & $\begin{array}{c}\text { Crystal } \\
\text { Formation }\end{array}$ \\
\hline 1 & Sarcinae & + & - & + & + & - & + & + \\
\hline 2 & Single cocci & + & + & + & - & + & + & - \\
\hline 3 & Rods in pairs & & + & + & - & + & + & + \\
\hline 4 & Diplococci & - & + & + & + & - & + & + \\
\hline 5 & Cocci in clusters & - & + & + & - & - & + & + \\
\hline 6 & Rods in pairs & - & + & + & - & - & + & + \\
\hline 7 & Filamentous & + & - & + & - & + & + & + \\
\hline 8 & Coccobacilli & - & - & - & - & - & - & - \\
\hline 9 & Diplobacilli & + & - & + & + & - & + & + \\
\hline 10 & Diplobacilli & + & - & & - & + & + & + \\
\hline 11 & Filamentous & + & - & + & + & + & + & + \\
\hline 12 & Single rods & - & + & + & - & + & + & + \\
\hline 13 & Single rods & - & + & + & - & + & + & + \\
\hline 14 & Single rods & + & - & + & - & - & + & + \\
\hline 15 & $\begin{array}{l}\text { Branched Fila- } \\
\text { mentous }\end{array}$ & - & - & + & - & + & + & + \\
\hline 16 & Single Rods & + & - & + & + & + & + & - \\
\hline 17 & Diplobacilli & - & + & $\mathrm{W}+$ & - & + & + & + \\
\hline 18 & Filamentous rods & + & - & + & - & + & + & + \\
\hline 19 & Filamentous & + & - & + & + & $\mathrm{W}+$ & - & - \\
\hline 20 & Short rods & $\mathrm{S}$ & - & + & - & + & + & + \\
\hline 21 & Filamentous & + & - & - & + & + & + & + \\
\hline 22 & Filamentous & + & - & + & + & - & + & + \\
\hline 23 & Filamentous & - & - & + & & $\mathrm{W}+$ & + & + \\
\hline 24 & Filamentous & + & - & $\mathrm{W}+$ & + & $\mathrm{W}+$ & + & + \\
\hline $25-2$ & Diplobacilli & - & + & $\mathrm{W}+$ & - & ++ & + & - \\
\hline 26 & Ovoid diplococci & - & - & - & - & - & + & - \\
\hline 27 & Long diplobacilli & - & - & + & $\mathrm{N}$ & - & + & - \\
\hline 28 & Diplococci & - & - & $\mathrm{W}+$ & $\mathrm{N}$ & + & + & - \\
\hline $29-1$ & Rods in pairs & - & - & - & - & - & + & + \\
\hline $29-2$ & Ovoid & $\mathrm{S}$ & - & + & + & - & - & - \\
\hline
\end{tabular}

Table 1: The list of results for cell morphology, gram staining and motility, catalase, amylase and urease tests as well as B-4 cultivability and crystal formation along with the sample codes

* Does not stained with gram staining, W+: Weak positive, N: No growth.

sity [20] also stated that hypogenic caves, such as limestone caves, are tend to show variability in terms of found dominant groups which also explains different dominant groups found in our study.

Within the Actinobacteria, most phylotypes were classified under the genus Micrococcus, Rhodococcus, Microbacterium, Streptomyces, Mycobacterium and Nocardia (Table 2). Two of the isolates are members of the same genus, Rhodococcus, however their morphologies were seen different. It was reported by researcher that this phylum are well known to sporulate under the nutrient low environment such as cave. Extracellular enzyme production and secondary metabolite production are important features of this phylum [23]. Also, they are known to produce $75 \%$ of the antibiotic compounds which are the most important secondary metabolite of microorganisms [24]. Also, researchers showed that large numbers of biogenic minerals were correlated by the phylum of Actinobacteria. Microorganisms play an important role in many different aspects in caves, it also influence on mineralogy such as mineral precipitation $[6,7]$. The mechanism of calcite and other formations that are seen in caves tried to be explained by using physical, chemical and biological approaches. Today, it is well know that 


\begin{tabular}{|c|c|c|c|c|c|}
\hline Sample Code & Phylum & Class & Order & Family & Genus \\
\hline 1 & Actinobacteria & Actinobacteria & Micrococcales & Micrococcaceae & Micrococcus \\
\hline 2 & Firmicutes & Bacilli & Bacillales & Staphylococcaceae & Staphylococcus \\
\hline 3 & Proteobacteria & $\alpha$-Proteo bacteria & Rhizobiales & Bradyrhizobiaceae & Bosea \\
\hline 4 & Proteobacteria & $\gamma$-proteo bacteria & Pseudomonadales & Pseudomonadaceae & Azotobacter \\
\hline 5 & Firmicutes & Bacilli & Bacillales & Planococcaceae & Viridibacillus \\
\hline 6 & Proteobacteria & $\alpha$-proteo bacteria & Rhizobiales & Bradyrhizobiaceae & \\
\hline 7 & Actinobacteria & Actinobacteria & Corynebacteriales & Nocardiaceae & Rhodococcus \\
\hline 8 & Proteobacteria & $\beta$-proteo bacteria & Burkholderiales & Comamonadaceae & Hydrogenophaga \\
\hline 9 & Actinobacteria & Actinobacteria & Micrococcales & Microbacteriaceae & Microbacterium \\
\hline 15 & Actinobacteria & Actinobacteria & Corynebacteriales & Nocardiaceae & Nocardia \\
\hline 16 & Firmicutes & Bacilli & Bacillales & Bacillaceae & Bacillus \\
\hline 17 & Proteobacteria & $\alpha$-proteo bacteria & Rhizobiales & Rhizobiaceae & $\begin{array}{c}\text { Sinorhizobium/Ensifer } \\
\text { group; Ensifer. }\end{array}$ \\
\hline 18 & Actinobacteria & Actinobacteria & Corynebacteriales & Nocardiaceae & Rhodococcus \\
\hline 19 & Actinobacteria & Actinobacteria & Streptomycetales & Streptomycetaceae & Streptomyces \\
\hline 20 & Actinobacteria & Actinobacteria & Corynebacteriales & Mycobacteriaceae & Mycobacterium \\
\hline 25 & Proteobacteria & $\alpha$-proteo bacteria & Rhizobiales & Rhizobiaceae & $\begin{array}{c}\text { Sinorhizobium/Ensifer } \\
\text { group; Ensifer. }\end{array}$ \\
\hline 26 & Bacteroidetes & Sphingo bacteria & Sphingobacteriales & Sphingobacteriaceae & Pedobacter \\
\hline
\end{tabular}

Table 2: The list of taxonomic rankings of each isolates presented from phylum to genus level identification.

most of the calcite formations are formed by microorganisms $[1,8]$. Calcium carbonate precipitation abilities were investigated of 210 bacteria that were isolated from soil and also could able to grow on B-4 medium by Bouquet., et al. They concluded that crystal formation is a general phenomenon that taking place when the media used under suitable conditions. Therefore the bacteria that cannot produce crystals may also produce these formations under a more favorable condition. During the culturing, the amount of the bacteria plated on the media was seen significant in order to obtain colonies. Isolates that plated in minimum amounts were not able to grow while with the increased amount resulted with the growth of the same isolate. This phenomenon may be explained by osmotic pressure $[18,25]$.

Proteobacteria was the second highest represented phylum in our study. In the present study, the identified genus under this phylum was Bosea, Azotobacter, Bradyrhizobiaceae, Hydrogenophaga and Sinorhizobium group (Table 2). Proteobacteria are a major research topic since they show extreme metabolic diversity and constitute bacteria known for medical, industrial and agricultural significance [26,27]. Members of Bosea, Azotobacter, Bradyrhizobiaceae and Sinorhizobium distinguish by their ability to fix nitrogen [28]. Most of the Hydrogenophaga members are known for their ability to use $\mathrm{H}_{2}$ and $\mathrm{CO}_{2}$ as their energy and carbon source respectively. Members of Burkholderia were diazotrophs and they able to degrade large number of xenobiotic compounds. Ikner., et al. [19] stated that Proteobacteria are more sensitive to $\mathrm{pH}$, temperature, nutrient or water stress. Therefore Proteobacteria are uncommon to found in cave environments while Firmicutes are known to be highly resistant to stress factors mentioned above hence expected to able to live in such conditions. Nevertheless our findings, as most of the cave researches conducted, are not supporting that statement since the Proteobacteria have been shown one of the dominant phyla of cave microbiota. Also their results suggested that Proteobacteria dominate where human contact is high. Gilindire Cave is open for tourism over a decade and high Proteobacteria rates may hint human contact but Gulecal-Pektas and Temel [22] showed high Actinobacteria (46-50\%) at the entrance of the touristic cave, Oylat. Furthermore, we found Staphylococcus which also signed of human impact in this cave.

The third most common phylum in our study was Firmicutes. Staphylococcus, Viridibacillus and Bacillus genus are found in Firmicutes phylum. Firmicutes are best known for their fermentative growth and can degrade complex polymers such as cellulose, pectin, xylan, chitin and lignin $[29,30]$. The ability to degrade complex compound give the bacteria the role of breaking down macromolecules entering the cave such as fungal matter, dead animal or plants thus, provide other energy and carbon sources for the microbial community of cave [31] Engel [31-42] pointed out Firmicutes and Actinobacteria are in an inverse correlation at the same community. The number Firmicutes are increasing when the number of Actino- 
bacteria decreasing and vice versa. Our results are also present an example to this statement since there is a gap between the percentages of these two phyla.

\section{Conclusion}

This is the first study performed in Gilindire Cave and one of few in Turkey. It is expected that these results will provide some insights about the Gilindire Cave not only about the diversity but also the potential energy dynamics of the cave. Additionally, the findings of soil associated bacteria in the Gilindire cave give us the insight about the connection between the surface environment and the cave walls.

Many different research area and experiments are left for the future due to lack of time and resources. Future work could include high throughput molecular techniques including metagenomics to reveal whole bacterial community of the Gilindire Cave.

\section{Acknowledgements}

This project has been funded by the Scientific Research Projects Department of Adana Science and Technology University with the project number 16303003.

\section{Bibliography}

1. Northup DE and Lavoie KH. "Geomicrobiology of Caves: A Review”. Geomicrobiology Journal 18.3 (2001): 199-222.

2. Northup DE., et al. "Diverse microbial communities inhabiting ferromanganese deposits in Lechuguilla and Spider Caves". Applied and Environmental Microbiology 5.11 (2003): 10711086.

3. Engel AS., et al. "Speciation of sulfur from filamentous microbial mats from sulfidic cave springs using X-ray absorption near-edge spectroscopy". FEMS Microbiology Letters 269.1 (2007): 54-62.

4. Onaga L. "Cashing in on nature's pharmacy: Bioprospecting and protection of biodiversity could go hand in hand". EMBO Reports 2.4 (2001): 263-265.

5. Barton HA. Introduction to cave microbiology: A review for the non-specialist (2006).

6. Jones B. "Microbes in caves: agents of calcite corrosion and precipitation". Geol. Soc. London, Spec. Publ. 336.1 (2010): 7-30.

7. Cuezva S., et al. "The biogeochemical role of Actinobacteria in Altamira Cave, Spain". FEMS Microbiology Ecology 81.1 (2012): 281-290.
8. Maciejewska M., et al. "Assessment of the potential role of Streptomyces in cave moonmilk formation". Frontiers in Microbiology (2017).

9. Engel AS. "Microbial diversity of cave ecosystems". In Geomicrobiology: Molecular and Environmental Perspective (2010): 219-238.

10. Aydın R. Searching for branched glycerol dialkyl glycerol tetraether membrane lipid producing bacteria in soil (2012).

11. Özşahin E and Kaymaz ÇK. “Gilindire (Aynalıgöl) Mğarasının Turizm Potansiyeli (Aydıncık, Mersin)”. Doğu Coğrafya Derg 19.31 (2014): 145.

12. Nazik L., et al. "Deniz kenarında bulunan polijenik bir mağara: Gilindire Mağarası (Aydıncık, içel), 54". Türkiye Jeol. Kurult. Bil$\operatorname{dir}(2000):$ 7-10.

13. Doetsch RN. "Determinative methods of light microscopy". Manual of Methods for General Bacteriology (1981): 21-33.

14. Prescott LM., et al. "Microbiology”. McGraw-Hill (2002).

15. Boquet E., et al. "Production of Calcite (Calcium Carbonate) Crystals by Soil Bacteria is a General Phenomenon". Nature 246 (1973): 527-529.

16. Baskar S., et al. "Microbially induced calcite precipitation in culture experiments: Possible origin for stalactites in Sahastradhara caves, Dehradun". India Current Science90.1 (2006): 58-64.

17. Park S., et al. Characterization of the Microbial Diversity in a Korean Solar Saltern by 16S rRNA Gene Analysis (2006).

18. Barton HA and Jurado V. "What's up down there? Microbial diversity in caves". Microbe 2.3 (2007): 132-138.

19. Ikner LA., et al. "Culturable microbial diversity and the impact of tourism in Kartchner Caverns, Arizona". Microbial Ecology 53.1 (2007): 30-42.

20. Ortiz-Ortiz M. "Kartchner Caverns: Habitat Scale Community Diversity and Fuartchner Caverns in order to gain insight into the distribution patterns associated with these communities. Secondly, the metabolic strategies used by cave communities to survive harsh cave condit". The University of Arizona (2012).

21. Ortiz M., et al. "Making a living while starving in the dark: metagenomic insights into the energy dynamics of a carbonate cave". The ISME Journal 8.2 (2014): 478-491. 
22. Gulecal-Pektas Y and Temel M. "Determination of microbial diversity in moon-milk deposits with next generation sequencing". Fresenius Environmental Bulletin 24.3 (2015).

23. Snel B., et al. "Genomes in Flux: The Evolution of Archaeal and Proteobacterial Gene Content". Genome Research 12.1 (2002): 17-25.

24. Zhang L and Demain AL. "Natural Products. Drug Discovery and Therapeutic Medicine Humana Press Inc., Totowa". Humana Press (2005).

25. Barış Ö. Isolation, Characterization and Identification of The Bacteria That Are Effective In Dripstone Formation In The Caves In Erzurum". Atatürk University (2009).

26. Marin I. "Proteobacteria. In Encyclopedia of Astrobiology". Springer Berlin Heidelberg, Berlin, Heidelberg (2011): 13501350.

27. Madigan M. "Brock Biology of Microorganisms”. 13th edn. In International Microbiology (2012).

28. Marcondes de Souza JA., et al. "The Family Bradyrhizobiaceae”. In The Prokaryotes. Springer Berlin Heidelberg, Berlin, Heidelberg (2014): 135-154

29. Bernardet JF and Nakagawa Y. An Introduction to the Family Flavobacteriaceae". In The Prokaryotes. Springer New York, New York, NY (2006): 455-480.

30. Vos, P., et al. "Bergey's Manual of Systematic Bacteriology: Volume 3: The Firmicutes". Springer Science and Business Media (2011).

31. Engel AS. "Microbial Life of Cave Systems". De Gruyter, Berlin, Boston (2015).

32. Banks ED., et al. "Bacterial Calcium Carbonate Precipitation in Cave Environments: A Function of Calcium Homeostasis". Geomicrobiology Journal 27.5 (2010): 444-454.

33. Bhullar K., et al. "Antibiotic resistance is prevalent in an isolated cave microbiome". PLoS One 7.4 (2012).

34. Buck JD. "Nonstaining $(\mathrm{KOH})$ method for determination of gram reactions of marine bacteria". Applied and Environmental Microbiology 44.4 (1982): 992-993.

35. Curry M., et al. "Cottonballs, a unique subaqeous moonmilk, and abundant subaerial moonmilk in Cataract Cave, Tongass National Forest, Alaska". International Journal of Speleology 38.2 (2009).
36. Danielli HMC and Edington MA. "Bacterial calcification in limestone caves". Geomicrobiology Journal 3 (1983): 1-16.

37. Joseph SJ., et al. "Laboratory cultivation of widespread and previously uncultured soil bacteria". Applied and Environmental Microbiology 69.12 (2003): 7210-7215.

38. Reasoner DJ and Geldreich EE. "A new medium for the enumeration and subculture of bacteria from potable water". Applied and Environmental Microbiology 49.1 (1985): 1-7.

39. Rinke C., et al. "Insights into the phylogeny and coding potential of microbial dark matter". Nature 499.7459 (2013): 431437.

40. Sanchez-Moral S., et al. "Biomediated Precipitation of Calcium Carbonate Metastable Phases in Hypogean Environments: A Short Review". Geomicrobiology Journal 20.5 (2003): 491500 .

41. Snider JR., et al. "Ultraviolet radiation sensitivity in cave bacteria: Evidence of adaptation to the subsurface?" International Journal of Speleology 38.1 (2009): 11-22.

42. Staley JT and Konopka A. "Measurement of in Situ Activities of Nonphotosynthetic Microorganisms in Aquatic and Terrestrial Habitats". Annual Review of Microbiology 39.1 (1985): 321-346.

\section{Assets from publication with us}

- Prompt Acknowledgement after receiving the article

- Thorough Double blinded peer review

- Rapid Publication

- Issue of Publication Certificate

- High visibility of your Published work

Website: https://www.actascientific.com/

Submit Article: https://www.actascientific.com/submission.php Email us: editor@actascientific.com Contact us: +919182824667 